\title{
Development Review of Research about Motivation on Employee Performance Topics over The Past Ten Years in Online Journals
}

\author{
Indah Wulansari \\ Accounting Major Faculty of Economic and Business, Universitas Trisakti \\ e-mail: indah.wlsr@gmail.com \\ Humaira Uswatun Hasanah \\ Accounting Major Faculty of Economic and Business, Universitas Trisakti \\ Jacqueline Lewaney \\ Accounting Major Faculty of Economic and Business, Universitas Trisakti \\ Tiarapuspa \\ Accounting Major Faculty of Economic and Business, Universitas Trisakti
}

\begin{abstract}
In an organization, motivation is the very important thing that it cannot be separated from employee performance. To get good performance, it is necessary to improve employee work motivation. Most employees need motivation to feel good about their jobs and perform optimally. Some employees are financially motivated while others find recognition and rewards personally motivating. A good leader will certainly create a comfortable environment and motivate employees with the aim that the enthusiasm for work and providing maximum performance. Work motivation is an important factor for obtaining good performance. This study aims to be a reference for researchers who plan to make research with the theme of motivation on employee performance so that researchers have a plan about what cases have been studied by previous researchers and then provide ideas for further development. The data in this study were taken from 30 articles over the past 10 years with the theme of motivation on employee performance and published in the Trijurnal Online Research Institute of Trisakti University and Emerald Insight Journals.
\end{abstract}

Keywords: Motivation, Employee, Performance

\section{INTRODUCTION}

Research on the topic of motivation on employee performance is very interesting to study because it has a very important role in developing a company's performance better and maximum. Motivation has been extensively researched. In the mid twentieth century the foremost significant motivational theories came up, namely Maslow's hierarchy of needs, Herzberg's two-factor theory and McClelland's expectancy theory. Those researches centered on motivation in general and employee motivation more particularly. According to Robbins and Timothy (2015), Maslow (2015) defined motivation as hierarchy of five needs which include physiological, safety, social, esteem, and self-actualization. Herzberg (2015) defined employee motivation as performing a workrelated action because you want to. McClelland (2015) defined motivation as theory of needs which theory that states achievement, power, and affiliation are three important needs that help explain motivation. Most employees need 
motivation to feel good about their jobs and perform optimally (Locke and Henne 2001). Some employees are money motivated while others find recognition and rewards personally motivating. Motivation levels within the workplace have a direct impact on employee productivity (Later Blau 2002). Workers who are motivated and excited about their jobs carry out their responsibilities to the best of their ability and production numbers increase as a result (Gustafsson 2005). An incentive is a motivating influence that is designed to drive behavior and motivate employees to produce quality work. Many employees need recognition from their employers to produce quality work. Recognition and employee reward systems identify employees who perform their jobs well (Kim 2001). Acknowledging a job well done makes employees feel good and encourages them to do good things.

Employees recognize workers by tracking progress and providing feedback about how they have improved over time (Porter, Steers, and Mowday 2004). Some employees are motivated through feeling a sense of accomplishment and achievement for meeting personal and professional goals. Many workers are self-disciplined and selfmotivated (Barnes 2006). Incentive and rewards have little effect on employees who feel motivated only when they are confident in their abilities and personally identify with their role within the organization (Harris and Mossholder 2006). Based on the background, the purpose of this research is to find out the influence motivation on employee performance. We have read and analyzed 30 articles published in journals throughout Indonesia over the past 10 years. This research will try to decipher historical data from several aspects, which from the dependent variable, the independent variable, the research methods, the samples, and the results of previous studies so that researchers can have a picture of what cases have been studied by previous researchers and provide ideas to develop new research potential.

\section{RESEARCH METHODS}

The methodology used in this study is by research from 30 articles with the topic of motivation on employee performance published on online journal websites for the past ten years. Next, the article is examined for its substance and grouped into a matrix whose columns consist of number, title, author, publisher, volume, year, purpose, method, sample, result, limitation/conclusion/further research. This are the journals:

Table 1. Journal

\begin{tabular}{|c|l|l|}
\hline No & \multicolumn{1}{|c|}{ Title } & \multicolumn{1}{c|}{ Author } \\
\hline 1 & $\begin{array}{l}\text { Flex-time as a moderator of the job stress-work } \\
\text { motivation relationship: A three nation investigation }\end{array}$ & $\begin{array}{l}\text { Barney, C.E. and Elias, S.M. } \\
(2010)\end{array}$ \\
\hline 2 & $\begin{array}{l}\text { Staff motivation in small food manufacturing } \\
\text { enterprises }\end{array}$ & $\begin{array}{l}\text { Bent, R., Seaman, C.E.A. and Ingram, A. } \\
(2010)\end{array}$ \\
\hline 3 & $\begin{array}{l}\text { Job crafting and motivation to continue working } \\
\text { beyond retirement age }\end{array}$ & $\begin{array}{l}\text { Lichtenthaler, P.W. and Fischbach, A. } \\
(2016)\end{array}$ \\
\hline 4 & $\begin{array}{l}\text { Korean Workers Motivation Tools: Commitment and } \\
\text { Incentive-Based Motivation and Their Relative } \\
\text { Impact on Behavioral Work Outcome }\end{array}$ & Lee, K.S. and Kulviwat, S. (2011) \\
\hline
\end{tabular}




\begin{tabular}{|c|c|c|}
\hline 5 & $\begin{array}{l}\text { Fashion and Social Networking: a motivations } \\
\text { framework }\end{array}$ & $\begin{array}{l}\text { Nelson, D.W., Moore, M.M. and } \\
\text { Swanson, K.K. (2019) }\end{array}$ \\
\hline 6 & $\begin{array}{l}\text { Examining the differences in salesperson motivation } \\
\text { among different cultures }\end{array}$ & $\begin{array}{l}\text { Moberg, C.R. and Leasher, M. } \\
\text { (2011) }\end{array}$ \\
\hline 7 & $\begin{array}{l}\text { From motivation to organizational commitment of } \\
\text { volunteers in non-profit sport organizations }\end{array}$ & $\begin{array}{l}\text { Bang, H., Ross, S. and Reio, T.G. } \\
(2013)\end{array}$ \\
\hline 8 & $\begin{array}{l}\text { The influence of motivation, organizational } \\
\text { commitment and job autonomy against the retention } \\
\text { of employees }\end{array}$ & Permatasari, L. (2013) \\
\hline 9 & $\begin{array}{l}\text { The influence of perceived organizational support } \\
\text { and the characteristics of the work of the employee } \\
\text { performance: Motivation as mediation variable PT. } \\
\text { Indosat }\end{array}$ & Samodra, W. (2014) \\
\hline 10 & $\begin{array}{l}\text { Faktor-faktor yang mempengaruhi motivasi kerja dan } \\
\text { kepuasan kerja pada pekerja berketerampilan rendah } \\
\text { atau terbatas }\end{array}$ & Pradiatiningtyas, D. (2010) \\
\hline 11 & $\begin{array}{l}\text { Motivation, pay satisfaction, and job satisfaction of } \\
\text { front-line employees }\end{array}$ & $\begin{array}{l}\text { Stringer, C., Didham, J. and } \\
\text { Theivananthampillai, P. (2011) }\end{array}$ \\
\hline 12 & Employee motivation: a Malaysian perspective & Islam, R. and Ismail, A.Z. (2010) \\
\hline 13 & $\begin{array}{l}\text { The mediating role of job satisfaction on the effect of } \\
\text { motivation to organizational commitment and work } \\
\text { engagement of private secondary high school in } \\
\text { Manila }\end{array}$ & Manalo, R.A. and Chin, U. (2020) \\
\hline 14 & $\begin{array}{l}\text { Mediating effect of intristic motivation on the } \\
\text { relationship between Islamic work ethic, job } \\
\text { satisfaction and organizational commitment in } \\
\text { banking sector }\end{array}$ & $\begin{array}{l}\text { Gheitani, A., Imani, S., Seyyedamiri, } \\
\text { N. and Foroudi, P. (2018) }\end{array}$ \\
\hline 15 & $\begin{array}{l}\text { Pengaruh Pelatihan dan Motivasi Kerja Terhadap } \\
\text { Kinerja Karyawan PT. BANK BJB Kantor Cabang } \\
\text { Suci Bandung }\end{array}$ & Rachmawati, R.W. (2016) \\
\hline 16 & $\begin{array}{l}\text { The Influence Of Intrinsic Motivation, Extrinsic } \\
\text { Motivation, And Competence Towards Accounting } \\
\text { Practice On Micro, Small, And Medium Enterprises } \\
\text { In Local Regency }\end{array}$ & $\begin{array}{l}\text { Wijayanti, D., Praptapa, A. and Irianto, } \\
\text { B.S. (2019) }\end{array}$ \\
\hline 17 & $\begin{array}{l}\text { Influence of Leadership Style and Work Motivation } \\
\text { on Employee Productivity of Employees in PT. } \\
\text { Asiatek Solution Indonesia }\end{array}$ & $\begin{array}{l}\text { Kusnadi, K., Yulianti, R. and Purnomo, } \\
\text { S.H. (2020) }\end{array}$ \\
\hline 18 & $\begin{array}{l}\text { Masihkah Job satisfaction dan motivation } \\
\text { memengaruhi organizational commitment? }\end{array}$ & $\begin{array}{l}\text { Murtiningsih, R.S and Tiarapuspa } \\
\text { (2019) }\end{array}$ \\
\hline 19 & $\begin{array}{l}\text { The Influence Of Ability And Work Motivation The } \\
\text { Employee's Underwriting To Have Performance In } \\
\text { The Insurance Company In Jakarta }\end{array}$ & Gunawan, H. (2016) \\
\hline 20 & $\begin{array}{l}\text { The Effect Of Career Development And Work } \\
\text { Motivation On Early Pension Desire }\end{array}$ & Nilasari, B.M. (2018) \\
\hline 21 & $\begin{array}{l}\text { Motivations for energy efficiency refurbishment in } \\
\text { owner-occupied housing }\end{array}$ & $\begin{array}{l}\text { Organ, S., Proverbs, D. and Squires, G. } \\
(2013)\end{array}$ \\
\hline 22 & $\begin{array}{l}\text { Adapting the congruent temperament model with } \\
\text { culturally specific work motivation elements }\end{array}$ & Humphreys, J. (2010) \\
\hline 23 & $\begin{array}{l}\text { Integrating public service motivation and self- } \\
\text { determination theory: A framework }\end{array}$ & Andrews, C. (2016) \\
\hline
\end{tabular}




\begin{tabular}{|c|l|l|}
24 & $\begin{array}{l}\text { Older workers' motivation to continue to work: five } \\
\text { meanings of age: A conceptual review }\end{array}$ & $\begin{array}{l}\text { Kooij, D., Lange, A., Jansen, P. and } \\
\text { Dikkers, J. (2010) }\end{array}$ \\
\hline 25 & $\begin{array}{l}\text { What motivates employees to engage in the social } \\
\text { economy sector? A case study of Greek cooperative } \\
\text { enterprises }\end{array}$ & $\begin{array}{l}\text { Sdrali, D., Rizou, M.G., Giannouli, P. } \\
\text { and Makris, K. (2016) }\end{array}$ \\
\hline 26. & $\begin{array}{l}\text { The effect of business process configurations on user } \\
\text { motivation }\end{array}$ & Torres, R. and Sidorova, A. (2015) \\
\hline 27. & $\begin{array}{l}\text { Enabling a motivated workforce: exploring the } \\
\text { sources of motivation }\end{array}$ & Ankli, R.E. and Palliam, R. (2012) \\
\hline 28. & Pengaruh Motivasi Terhadap Kepuasan Kerja & Ferdyan, F. (2014) \\
\hline 29. & $\begin{array}{l}\text { The Influence Of Ability And Work Motivation The } \\
\text { Employee's Underwriting To Have Performance In } \\
\text { The Insurance Company In Jakarta }\end{array}$ & Gunawan, H. (2016) \\
\hline 30. & Analysis of factors influencing Work Motivation & Immanullah, M. (2010) \\
\hline
\end{tabular}

\section{FINDING AND DISCUSSION}

Based on a literature study that has been conducted on 30 articles about motivation on employee performance, information can be obtained that as many as 27 articles (90\%) use motivation as an independent variable and have a significant positive relationship to the dependent variable. From the data obtained, it can also be concluded that $10 \%$ of the studies did not find evidence of a significant positive relationship with the independent variable.

Based on several articles that have been collected by the author, the author can conclude that most of the research methods carried out in 30 articles, it is known that $33 \%$ of the articles use the method of using the interview and questionnaire survey method, one of the reasons why many researchers who like the method is the information obtained directly from the first source. One article that uses the interview method and questionnaire survey method is Staff motivation in small food manufacturing enterprises (Bent, R., Seaman, C.E.A. and Ingram, A. 2010), Pengaruh Pelatihan dan Motivasi Kerja Terhadap Kinerja Karyawan PT. BANK BJB Kantor Cabang Suci Bandung (Rachmawati, R.W. 2016), The mediating role of job satisfaction on the effect of motivation to organizational commitment and work engagement of private secondary high school in Manila (Manalo, R.A. and Chin, U. 2020), Masihkah Job satisfaction dan motivation memengaruhi organizational commitment? (Murtiningsih, R.S and Tiarapuspa. 2019), The Effect Of Career Development And Work Motivation On Early Pension Desire (Nilasari, B.M. 2018), The Influence Of Intrinsic Motivation, Extrinsic Motivation, And Competence Towards Accounting Practice On Micro, Small, And Medium Enterprises In Local Regency (Wijayanti, D., Praptapa, A. and Irianto, B.S. 2019) and each others.

As many as $17 \%$ of articles use the Structural Equation Modeling (SEM) method. SEM is a statistical technique used to construct and test statistical models that are usually in the form of causal models. SEM is actually a hybrid technique that includes the confirmatory aspects of factor analysis, path analysis and regression that can be considered as special cases in SEM. Some articles that use the SEM method are The influence of perceived organizational support and the characteristics of the work of the employee performance: Motivation as mediation variable PT. Indosat (Samodra, W. 2014), From motivation to organizational commitment of volunteers in non-profit sport 
organizations (Bang, H., Ross, S. and Reio, T.G. 2013), The influence of motivation, organizational commitment and job autonomy against the retention of employees (Permatasari, L. 2013), Korean Workers Motivation Tools: Commitment and IncentiveBased Motivation and Their Relative Impact on Behavioral Work Outcome (Lee, K.S. and Kulviwat, S. 2011), and Job crafting and motivation to continue working beyond retirement age (Lichtenthaler, P.W. and Fischbach, A. 2016)

Also several other methods such as $U \& G$ research, Hypothesis based on previous cross-cultural and motivation research, The nordic employee index model, Sampling collection, Data analyzed, Question \& researcher interaction with employees, Hierarchical moderated multiple regression and Literature review

Based on the data found by the author, many researchers conducted research in the banking sector as in the article titled Mediating the effects of intristic motivation on the relationship between Islamic work ethics, job satisfaction and organizational commitment in the banking sector (Gheitani, A., Imani, S., Seyyedamiri, N. and Foroudi, P. 2018), Influence Of Training And Motivation Work On Employee Performance PT. Bank BJB Suci Bandung Branch Office (Rachmawati, R.W. 2016), manufacturing sector companies as in the Staff motivation article in small food manufacturing enterprises (Bent, R., Seaman, C.E.A. and Ingram, A. 2010), and research in the education sector as in the article The mediating role of job satisfaction on the effect of motivation to organizational commitment and work engagement of private secondary high school in Manila (Manalo, R.A. and Chin, U. 2020), there is also work motivation research in non-profit organizations as in the article From motivation to organizational commitment of volunteers in non-profit sport organizations (Bang, H., Ross, S. and Reio, T.G. 2013).

\section{CONCLUSIONS}

A literature study has been conducted on 30 articles from several websites over the past 10 years. Based on the description of information obtained from the study, it can be concluded that:

1. The independent aspect of the variables of 30 articles that discuss themes about motivation over the past 10 years, can be found that $90 \%$ of researchers conducted research by including aspects of motivation.

2. Based on the results of research on 30 articles that raise the theme of employee performance and make motivation an independent variable, it can be found that as much as $90 \%$ obtained significantly positive results

3. The majority of research uses qualitative methods by Interview, questionnaires survey method and Structural equation modeling

\section{REFERENCE}

Andrews, C. 2016. Integrating Public Service Motivation And Self-Determination Theory: A Framework. Vol 29 No. 3, Page 238-254

Ankli E.R., and Palliam R. 2012. Enabling A Motivated Workforce: Exploring The Sources Of Motivation. Vol 26 No. 2, Page 7-10 
Bang, H., Stephen R., and Thomas G.R.Jr. 2013. From Motivation To Organizational Commitment Of Volunteers In Non-Profit Sport Organizations. Vol 32 No.1 Page 96-112

Barney E.C. and Steven M.E. 2010. Flex-Time As Moderator Of The Job Stress-Work Motivation Relationship: A Three Nation Investigation. Vol 39 No. 4, Page 487502

Blau, G. 2002. On Developing A General Index Of Work Commitment. Journal of Vocational Behavior. Vol 42, Page 298-314

Claire E.A.S., Richard B., and Arthur I. 2010. Staff Motivation in Small Food Manufacturing Entreprises. Vol 101 No. 9, Page 654-667

Ferdyan, F. 2014. Pengaruh Motivasi Terhadap Kepuasan Kerja. Vol 14 No. 2, Page $75-112$

Gheitani A., Imani S., Seyyedamiri N., and Foroudi P. 2018. Mediating Effect Of Intristic Motivation On The Relationship Between Islamic Work Ethic, Job Satisfaction And Organizational Commitment In Banking Sector. Vol. 12 No. 1, Page 76-95

Gunawan, H. 2016. The Influence of Ability and Work Motivation The Employee's Underwriting to Have Performance In The Insurance Company In Jakarta. Vol 16 No. 1, Page 45-62

Gustaffson, A. 2005. The Effects Of Customer Satisfaction, Relationship Commitment Dimensions And Triggers On Customer Retention. Vol 69, Page 210-218

Harris, S., and Mossholder. 2006. The Affective Implications Of Perceived Congruence With Culture Dimensions During Organizational Transformation. Vol 22 Page 527-547

Humphreys, J. 2010. Adapting The Congruent Temperament Model With Culturally Specific Work Motivation Elements. Vol 14 No. 3, Page 202-216

Immanullah, M. 2010. Analysis Of Factors Influencing Work Motivation. Vol 7 No.1, Page 35-43

Islam R., Zaki Hj. I. A. 2008. Employee Motivation: A Malaysian Perspective. Vol. 18 No. 4, Page 344-362

Kim, K.I. 2001. The Impact Of Cultural Collectivism On Reward Allocation. Vol 47, Page 793-804

Kooij D., Lange D.A., Jansen P., Dikkers J. 2011. Older Workers' Motivation To Continue To Work: Five Meanings Of Age: A Conceptual Review. Vol 23 No.4, Page 364-394

Kusnadi, K., Yulianti R., and Hadi P. S. 2020. Influence Of Leadership Style And Work Motivation On Employee Productivity Of Employees In PT. Asiatek Solution Indonesia. Vol. 20 No. 1, Page 79-98 
Lee S.K. and Songpol K. 2011. Korean Workers' Motivation Tools: Commitment And Incentive-Based Motivation And Their Relative Impact On Behavioral Work Outcome. Vol 16 No.4, Page 87-110

Lichtenthaler, W. P. and Andrea F. 2016. Job Crafting and Motivation to Continue Working Beyond Retirement Age. Vol 21 No. 5, Page 477-497

Manalo, R.A. and Chin, U. 2020. The Mediating Role Of Job Satisfaction On The Effect Of Motivation To Organizational Commitment And Work Engagement Of Private Secondary High School In Manila. Vol 9 No. 1

Medina, N.B. 2018. The Effect Of Career Development And Work Motivation On Early Pension Desire. Vol 18 No. 1, Page 75-92

Moberg, R.C., and Megan L. 2011. Examining the Differences in Salesperson Motivation among Different Cultures. Vol 26 No. 2, Page 145-5181

Nelson, W. D., Marguerite M. M., and Kristen K. S. 2019. Fashion and Social Networking: a Motivation Framework. Vol 23 No. 4, Page 1361-2026

Organ, S., Proverbs D,, and Squires G. 2013. Motivations for energy efficiency refurbishment in owner occupied housing. Vol 31 No. 2, Page 101-120

Permatasari, L. 2013. The Influence of Motivation, Organizational Commitment and Job Autonomy Against The Retention of Employees. Vol 13 No. 2, Page 123-138

Porter, L.W.R., Steers, R.T., and Mowday. 2004. Organizational Commitment, Job Satisfaction, And Turnover Among Psychiatric Technicians. Vol 59, Page 603-609

Pradiatiningtyas, D. 2010. Faktor-Faktor yang Mempengaruhi Motivasi Kerja dan Kepuasan Kerja Pada Pekerja Berketerampilan Rendah atau Terbatas. Vol 7 No. 2, Page 179-196

Robbins, P. S., and Timothy A. J. 2015. Organizational Behavior. $16^{\text {th }}$ edition. Harlow: Pearson.

Samodra, W. 2014. The Influence of Perceived Organizational Support and The Characteristics of The Work of The Employee Performance: Motivation as Mediation Variable PT. Indosat. Vol 13 No. 2, Page 175-192

Sari M. R., and Tiarapuspa. 2019. Masihkah Job satisfaction dan motivation memengaruhi organizational commitment?. Vol 12 No. 1, Page 147-164

Sdrali, D., Goussia-Rizou M., Giannouli P., and Makris K. 2016. What Motivates Employees To Engage In The Social Economy Sector? A Case Study Of Greek Cooperative Enterprises. Vol 43 No.12, Page 1334-1350

Stringer, C., Didham J., dan Theivananthampillai P. 2011. Motivation, Pay Satisfaction, And Job Satisfaction Of Front-Line Employee. Vol. 8 No. 2, Page 161-179

Sugiyono. 2016. Metode Penelitian Kuantitatif, Kualitatif dan R\&D. Bandung: PT Alfabet. 
Torres, R., and Sidorova A. 2015. The Effect Of Business Process Configurations On User Motivation. Vol 21 No. 3, Page 541-563

Watie, R. R. 2016. Pengaruh Pelatihan Dan Motivasi Kerja Terhadap Kinerja Karyawan Pt. Bank Bjb Kantor Cabang Suci Bandung. Vol 9 No. 1

Wijayanti, D., Praptapa A., and Setyobudi I. B. 2019. The Influence Of Intrinsic Motivation, Extrinsic Motivation, And Competence Towards Accounting Practice On Micro, Small, And Medium Enterprises In Local Regency. Vol 19 No. 1, Page 69-86 